\title{
An Analysis of Music Courses Offered in the Primary School Teacher Education Programs in Turkey
}

\author{
İlhan ÖZGÜL ${ }^{1}$ \\ ${ }^{1}$ Department of Fine Arts Education, Education Faculty, Kastamonu University, Kastamonu, Turkey \\ Correspondence: İlhan ÖZGÜL, Department of Fine Arts Education, Education Faculty, Kastamonu University, \\ 37200, Kastamonu, Turkey. E-mail: ilhanozgul@kastamonu.edu.tr
}

Received: September 30, 2016

Accepted: October 30, 2016

Online Published: March 29, 2017

doi:10.5539/ies.v10n4p8

URL: https://doi.org/10.5539/ies.v10n4p8

\begin{abstract}
The aim of this study was to analyze music courses applied within the scope of compulsory courses in the primary school teacher training model in Turkey. Being qualitative in nature, the current study utilized document analysis method. Towards the stated aim, four approaches were discussed. The first one is related to the titles of the music courses stipulated in the primary school teachers training process and the credits/hours allocated for the music courses during the university schooling period in Turkey since 1974. The second one covers the preparation and general quality of the music course standards applied up to now. The third one is related to music course standards and appearance of these standards in the current teaching program, and the last one is related to the analysis of "music and "music teaching curriculum framework" in terms of the expected behavior stated in the music teaching programs. In program analysis, three approaches were applied: Designed program analysis, conducted program analysis, and actualized program analysis.
\end{abstract}

Keywords: teacher training, primary school teacher, music teaching program, music courses in Turkey

\section{Introduction}

Primary school teacher training programs in Turkey offer compulsory music courses in two semesters. These courses aims for teacher candidates to gain positive attitudes towards the importance of music in life, to understand and explore how music is created, produced and communicated, including through the inter-related dimensions: pitch, duration, dynamics, tempo, timbre, texture, structure and appropriate musical notations, to demonstrate holistic approach during conducting, teaching and learning of music lessons in elementary schools and to overcome the obstacles faced during the teaching of music lessons. Moreover, among the primary responsibilities of music educators is to determine effective strategies to encourage student to ensure that learning is taking place and the musical goals are attained.

Primary education in Turkey consists of the grades 1 through 8 that cover the ages 6-14. The eight-year process of primary education is divided into "two stages". The first stage, named as "primary school," includes the grades 1 through 4; while, the second stage, named as "middle school," covers the grades 5, 6, 7 and 8. In line with the directives of the Ministry of National Education, music courses are provided by primary school teachers at the primary school level while it was instructed by music teachers at the middle school level (MEB 2006, 2008).

Since 1923 when the Republic of Turkey was announced, teaching programs consisted of directives that could be considered as teaching regulations, draft programs, course schedules, teaching curricula that include subject contents to be covered in the lessons. Teaching program of 1994 that interiorized behaviourist approach emphasized objectives and expected behaviours for each content domain, described teaching-learning situations and assessment and evaluation techniques; on the other hand, the teaching program, being effective in 2006, adopted constructivism, highlighted learning areas, and defined targeted behaviors, activities, explanations and assessments for each learning area (Özgül, 2009). Because of some social and political concerns and (in some cases such as foundation of village institutes) with the recommendations of the academicians from inside and abroad (such as Dewey), teacher education process in Turkey underwent prominent changes and were divided into periods, namely two-year Education Institutes period (1974-1983), two-year Education High School period (1983-1989), four-year High School period (1989-1992), Education Faculty Primary School Teacher Training Program Period (1992-1997). According to Ataman (1997), an analysis of distinctive aspects, design samples and 
application methods of primary school teacher training programs points out a change in courses titles with the same content coverage and credit hours (Ataman, 1997).

Music teaching curriculum covers all regulations and activities towards realizing expected music learning from students. In this regard, music-teaching curriculum is multiple faced, multi-dimensional and comprehensive. Main sub-themes covered in music teaching program are music teaching curriculum, music course curriculum, curriculum of individual and group concert activity, curriculum of extracurricular activities, course and pedagogical branch activities about music, curriculum of consultation and guidance about music, curriculum of method and working about music, curriculum of supportive services about music and regulations and directives about music. The main focus of music education curriculum is "music teaching curriculum". Other sub-elements are generally the ones which are complement and complete (Özgül, 2014; Uçan, 2005).

Music educators, in order to create these mindful classrooms, need to build an ongoing model of musical development; model musical thinking and reflective thought; design engaging, open-ended experiences; practice masterful perception; draw upon a repertoire of representations; collect evidence of students' thinking; and embed assessment in curriculum and instruction (Barett, 2005). The followings are the four significant questions that are being asked concerning making sense of the curriculum development process with an analytical view of the curriculum or concerning guiding the curriculum development. Who am I? Who are my students? What might they become? What might we become together? (Abrahams, 2005). They can sometimes also answer a fifth question: What else (other than music) did the students learn? (Mills, 2005).

The education process was discussed from a broad perspective in this context. The contents of music and music education lessons are presented within a theoretical framework in this study, gathering a series of facts such as the general music education process, conducted for a long time, trials in the classroom, practices, correction, research and development and professional experience and knowledge. The analysis aims to make contribution to all of general music education processes and so it is thought that this will bring to light some new approaches/situations concerning the general music education process management in terms of both program and the educators. In order to provide qualified and productive education, music educators, who govern this process, should internalize the music teaching program. Within this regard, the current study aimed to analyze music courses applied in training of primary school teachers in Turkey in terms following perspectives/approaches.

- Time allocation (credit hours) for music courses offered in primary school teacher training programs under governance of universities

- Preparation and general quality of music course designs adopted in the primary school teacher training programs

- Standards of music courses offered in the primary school teacher training programs

- Analysis of music course contents in terms of expected behaviors stated in the primary school teacher training programs

\section{Methodology}

Being qualitative in nature, this study conducted document analysis method that includes analysis of written sources about phenomena that is targeted in the research. In qualitative studies, as document analysis could be used as a unique data collection method, it may also be conducted with other research methods (Yildirım, 2005). The document analyses require explaining the meaning of the document and exemplifying and interpreting the document in order to give it a deeper meaning (Yıldırım \& Şimşek, 2005). In scientific usage, a phenomenon is any event that is observable, however common it might be, even if it requires the use of instrumentation to observe, record, or compile data concerning it (Phenomenalism, 2017). Data were collected from the primary school teacher education programs in Turkey that have been applied since 1974. During the data analysis, descriptive analysis and program analysis techniques were utilized. According to Uçan (2002), program analysis is a process that includes determining the quality of the program, organizing and decomposing relationship between components of the program, and determining the bases and the tendencies of the program components. In this process, students' readiness and learning levels were described through content analysis in terms of applications associated with music and music teaching courses, and behaviors that were carried in or expected from the contents that were suggested by means of experiences and observations. Music and music teaching courses were presented in a theoretical frame through analysis of behaviors that are included or expected to be included in the music units. Theoretical framework included the steps of investigating, experimenting, revising, and improving definitional curriculum designs. 


\section{Findings}

In this section has present the findings obtained from the program analysis and has be gathered under general quality and preparation of music curriculum, credit/hours allocated to music courses in primary school teacher training programs, appearance of music course standards in the curricula between 1998 and 2006, and music course contents in terms of expected behaviors defined in the primary school teacher training programs.

\subsection{General Quality and Preparation of Music Curriculum}

\subsubsection{General Quality}

Music education has been contained as a compulsory education area in the programs of all institutions that train primary school teachers since the foundation of the Republic. The music education applied in all primary school teacher training models is based on general music education or in the professional music education, which is within the general music education. The curricula which are applied at the pre-undergraduate, undergraduate, and graduate levels in most universities are based on the definitional curriculum model. This model is generally made up of a definition that briefly describes the scope and content of a course. Definitions could mostly be content, operation or activity weighted; partly goal or behavior weighted, repertoire weighted, or materials weighted. The definitional curriculum defines what is going to be done in a course. The definition constitutes the basis for the teaching plan (in detail), which is supposed to be prepared by the instructor (Özgül, 2001).

\subsubsection{Preparation}

The Project of Developing the National Education for the purpose of training pre-service teachers, which was launched by Higher Education Council and the World Bank in 1994, covered faculties of education who were responsible from training primary and secondary school teachers. Among the main purpose of the project, which ended in 1998, was to identify the targets of the special teaching methods course in subject areas, to prepare education curricula and to relate these curricula to teachers' professional preparation at schools. Authors and panel members were formed for each subject area of primary and secondary school curricula. Authors of music area and panel members were loaded of the work of determining the contents of a guide book prepared under the name "music teaching," suggested methods about music teaching and introduced these methods to music teaching lecturers and other lecturers who are interested with music teaching. Higher Education Council updated teacher training curricula in the faculties of education in 2006.

\subsection{Credit/Hours Allocated To Music Courses in Primary School Teacher Training Programs}

Table 1 shows distribution of credits and hours allocated to music courses and music course titles offered in primary school teacher training programs among the teacher education periods. As seen in Table 1, music courses are allocated 6 credit/hours among the curriculums of primary school teacher training between 1974 and 2006. On the other hand, percentage distribution of music course hours compared to time allocation for all courses were increased until four-year education faculty period (1989-1992), and declined in the following periods. In the curriculum of primary school teacher training, the duration and name of the courses had underwent some changes; some courses were added to the curriculum. Parallel to this, the students' graduation credits increased/decreased, but there was no change in credits/hours allocated to the music courses. Until 1989, Music and Teaching was the only course offered for the primary school teacher trainees while it was divided into two separate courses (Music and Music Teaching) in 1989. The name of Music Course also changed as Music I and Music II between 1992-2006. Finally, music courses in primary school teacher education programs were renamed as Music and Music Teaching in the 2006 curriculum.

Table 1. Credits and hours allocated to music courses and the naming of music courses

\begin{tabular}{|c|c|c|c|c|c|c|c|c|c|c|c|}
\hline \multicolumn{2}{|c|}{$\begin{array}{c}\text { Two-year education } \\
\text { institutions } \\
(1974-1983)\end{array}$} & \multicolumn{2}{|c|}{$\begin{array}{c}\text { Two-year high school } \\
\text { (1983-1989) }\end{array}$} & \multicolumn{2}{|c|}{$\begin{array}{c}\text { Four-year higher } \\
\text { education } \\
(1989-1992)\end{array}$} & \multicolumn{2}{|l|}{$\begin{array}{c}\text { Department of } \\
\text { Primary School } \\
\text { Teaching } \\
\text { (1992-1997) }\end{array}$} & \multicolumn{2}{|c|}{$\begin{array}{c}\text { Section of primary } \\
\text { school teaching } \\
(1998-2006)\end{array}$} & \multicolumn{2}{|c|}{$\begin{array}{c}\text { Section of primary } \\
\text { school teaching } \\
(2006-\ldots)\end{array}$} \\
\hline $\begin{array}{l}\text { The name of the } \\
\text { course }\end{array}$ & $\mathrm{c} / \mathrm{h}$ & $\begin{array}{l}\text { The name of the } \\
\text { course }\end{array}$ & $\mathrm{c} / \mathrm{h}$ & $\begin{array}{l}\text { The name of the } \\
\text { course }\end{array}$ & $\mathrm{c} / \mathrm{h}$ & $\begin{array}{l}\text { The name of the } \\
\text { course }\end{array}$ & $\mathrm{c} / \mathrm{h}$ & $\begin{array}{l}\text { The name of the } \\
\text { course }\end{array}$ & $\mathrm{c} / \mathrm{h}$ & $\begin{array}{l}\text { The name of } \\
\text { the course }\end{array}$ & $\mathrm{c} / \mathrm{h}$ \\
\hline $\begin{array}{l}\text { Music and } \\
\text { teaching first } \\
\text { year, first } \\
\text { semester }\end{array}$ & 2 & $\begin{array}{l}\text { Music and } \\
\text { teaching (first } \\
\text { year, first } \\
\text { semester) }\end{array}$ & 2 & $\begin{array}{c}\text { Music } \\
\text { (second year, } \\
\text { third semester) }\end{array}$ & 2 & $\begin{array}{l}\text { Music-1 } \\
\text { (second year } \\
\text { third semester) }\end{array}$ & 2 & $\begin{array}{l}\text { Music-1 } \\
\text { (second year, } \\
\text { third semester) }\end{array}$ & 2 & $\begin{array}{c}\text { Music } \\
\text { (second year, } \\
\text { third } \\
\text { semester) }\end{array}$ & 3 \\
\hline
\end{tabular}




\begin{tabular}{|c|c|c|c|c|c|c|c|c|c|c|c|}
\hline $\begin{array}{l}\text { Music and } \\
\text { teaching (first } \\
\text { year, second } \\
\text { semester) }\end{array}$ & 2 & $\begin{array}{l}\text { Music and } \\
\text { teaching (first } \\
\text { year, second } \\
\text { semester) }\end{array}$ & 2 & $\begin{array}{c}\text { Music } \\
\text { (second year, } \\
\text { fourth semester) }\end{array}$ & 2 & $\begin{array}{c}\text { Music-2 } \\
\text { (second year, } \\
\text { fourth semester) }\end{array}$ & 2 & $\begin{array}{l}\text { Music-2 } \\
\text { (second year, } \\
\text { fourth semester) }\end{array}$ & 2 & $\begin{array}{l}\text { Music } \\
\text { teaching } \\
\text { (2.grade, } \\
\text { 4.term) }\end{array}$ & 3 \\
\hline $\begin{array}{l}\text { Music and } \\
\text { teaching (second } \\
\text { year, third } \\
\text { semester }\end{array}$ & 2 & $\begin{array}{c}\text { Music and } \\
\text { teaching (second } \\
\text { year, third } \\
\text { semester) }\end{array}$ & 2 & $\begin{array}{l}\text { Music teaching } \\
\text { (third year, fifth } \\
\text { semester) }\end{array}$ & 2 & $\begin{array}{l}\text { Music teaching } \\
\text { (third year, fifth } \\
\text { semester) }\end{array}$ & 2 & $\begin{array}{l}\text { Music teaching } \\
\text { (third year, fifth } \\
\text { semester) }\end{array}$ & 2 & ------- & \\
\hline Toplam & 6 & & 6 & & 6 & & 6 & & 6 & 6 & \\
\hline Total credits: 10 & & 142 & & 191 & & 162 & & 157 & & 154 & \\
\hline
\end{tabular}

Citation: Özgül (2001). c/h: credit hour.

\subsection{Appearance of Music Course Standards in the Curricula between 1998 And 2006}

A close examination of the statements in the music course standards yields that the curriculum standards involve a definition composed of expressions 'Education Status and Education Status with Appearance', 'Unit/Subject heading', 'Partial target', with target behavior appearance. Hence, this section will analyze each period under these headings.

Music and music teaching course contents of primary school teaching program, which were applied about 10 years from 1998 to the present day, are shown below.

- The 1998 Music Curriculum is shown below.

Music-1: Music in education; the role and content of music, basic music knowledge, nature and aim of writing notes, introduction to instrument and voice training, collective performing and singing, musical hearing reading writing work in improving creativity.

Music 2: work of acquainting with, listening to, voicing and composing music elements; historical view of music, musical structures in other cultures, improvement of musical skills; instrument, voice and note training, subjects suitable for units in music, children's music with plays.

Music Teaching: Examination of first stage music course curriculum in primary education; relation of music with other courses; music teaching methods and techniques applied in primary education first stage; preparation of music course plans, evaluation of the performance, class management in music teaching, improvement of musical skills; work of listening, singing, performing and composing.

Table 2. The appearance of the 1998 curriculum music course contents

\begin{tabular}{|c|c|}
\hline Its kind & Examples of expression \\
\hline $\begin{array}{l}\text { Education Status, Education } \\
\text { Status with Appearance }\end{array}$ & $\begin{array}{l}\text { - } \text { Practices of musical hearing, reading and writing in improving creativity } \\
\text { - } \quad \text { Work of performing and composition } \\
\text { - } \quad \text { Training of musical instruments, sound and notes } \\
\text { - } \quad \text { Examination of music course curriculums in Stage I in Primary Education } \\
\text { - } \quad \text { Preparation of music course plans } \\
\text { - } \quad \text { Evaluation of performance } \\
\text { - Improvement of music skills } \\
\text { - } \quad \text { Work of performance and composition }\end{array}$ \\
\hline Unit/Subject Headings & $\begin{array}{l}\text { - } \text { The role and content of music in education } \\
\text { - } \text { Introduction to musical instrument and sound training } \\
\text { - } \quad \text { Basic music knowledge } \\
\text { - } \quad \text { Musical structures in other cultures } \\
\text { - } \quad \text { The nature and aim of writing notes } \\
\text { - } \\
\text { - } \\
\text { Educthods and techniques of music teaching applied in Stage I in Primary } \\
\text { Class management in music teaching }\end{array}$ \\
\hline
\end{tabular}




\begin{tabular}{lll}
\hline & - Collective playing and singing \\
Partly target/with the appearance & - Recognizing music elements \\
of target behavior & - Listening \\
& • & Singing \\
\hline Materials & - & Children's music, plays \\
\hline
\end{tabular}

Citation: YÖK (1998).

- The 2006 music course contents are shown below.

Music: Basic components of music, basic music knowledge; knowledge of notes, interval concept in music, rhythm concept in music, formation of songs repertoire; music genres and forms in Turkey and in the world; transition from traditional music to contemporary music, instruments teaching, collective performing and singing, role of music in education, musical hearing in improving creativity.

Music Teaching: Music teaching methods and techniques, notes teaching techniques, arrangement of songs for children with Orff instruments by making use of rhythm and melody, effective use of instruments in songs teaching, relation of plays, music, dance, drama and speaking, improvement of musical liking through music - aesthetic relations, relation of music course activities to other disciplines, activity practices on primary education music curriculum.

Table 3. The appearance of the 2006 curriculum music course contents

\begin{tabular}{|c|c|}
\hline Kind & Examples of expression \\
\hline $\begin{array}{l}\text { Education status, education status } \\
\text { with appearance }\end{array}$ & $\begin{array}{ll}\text { - } & \text { Formation of repertoire } \\
\text { - } & \text { Teaching of musical instruments } \\
\text { - } & \text { Active use of musical instruments in teaching songs } \\
\text { - } & \text { Relation of music course activities to other disciplines } \\
\text { - } & \text { Activity practices on primary education music curriculum } \\
\text { - } & \text { Arrangement of songs for children with Orff musical instruments by making use of } \\
\text { rhythm and melody }\end{array}$ \\
\hline Unit/Subject heading & $\begin{array}{ll}\text { - } & \text { Basic components of music } \\
\text { - } & \text { Basic music knowledge } \\
\text { - } & \text { Note knowledge } \\
\text { - } & \text { The concept of interval in music } \\
\text { - } & \text { The concept of rhythm in music } \\
\text { - } & \text { Genres and forms of music in Turkey and in the world } \\
\text { - } & \text { The role of music in education } \\
\text { - } & \text { Transition from traditional music to contemporary music } \\
\text { - } & \text { Methods and techniques of music teaching } \\
\text { - } & \text { Techniques of note teaching } \\
\text { - } & \text { The relation of game, music, dance, drama and speaking } \\
\end{array}$ \\
\hline $\begin{array}{l}\text { Partial target/with the appearance } \\
\text { of target behavior }\end{array}$ & $\begin{array}{l}\text { - } \quad \text { Collective playing and singing } \\
\text { - } \quad \text { Listening to music in improving creativity } \\
\end{array}$ \\
\hline Materials & $\begin{array}{ll}\cdot & \text { Plays } \\
\cdot & \text { Music } \\
\end{array}$ \\
\hline
\end{tabular}

Citation: YÖK (2006).

\subsection{Music Course Contents In Terms Of Expected Behaviors Defined in the Primary School Teacher Training Programs}

Teaching program is generally regarded as a program that are consisted of knowledge categories, that provide great emphasis on skills and practice, and that aim to gain planned skills and knowledge in accordance with the objectives defined in the program (Küçükahmet, 1996). Music teaching is a learning process towards achieving expected behaviors in the environment that supports students' interaction (Uçan, 2005). Moreover, music teaching is the reflection of the application of the predetermined lesson designs. Within this context, future 
directions and suggestions, music textbooks with different approaches for music education in primary school teacher training programs are analyzed (Akkaş, 2005; Barett 2005, 2007; Battersby, 2014; Çicek, 2000; Kalyoncu, 2009; Kocabaş, 2003; Morgül, 2001; Stock, 2002; Overland, 2013; Özgül 2001, 2009, 2015; Meb, 1994; Yök, 1998, 2006; Yıldız, 2002). Moreover, students' readiness and learning levels were described through content analysis in terms of applications associated with music and music teaching courses, and behaviors that were carried in or expected from the contents that were suggested by means of experiences and observations.

\subsubsection{Analysis of "Music" Course Content}

Table 4. Analysis of the "Music" course content

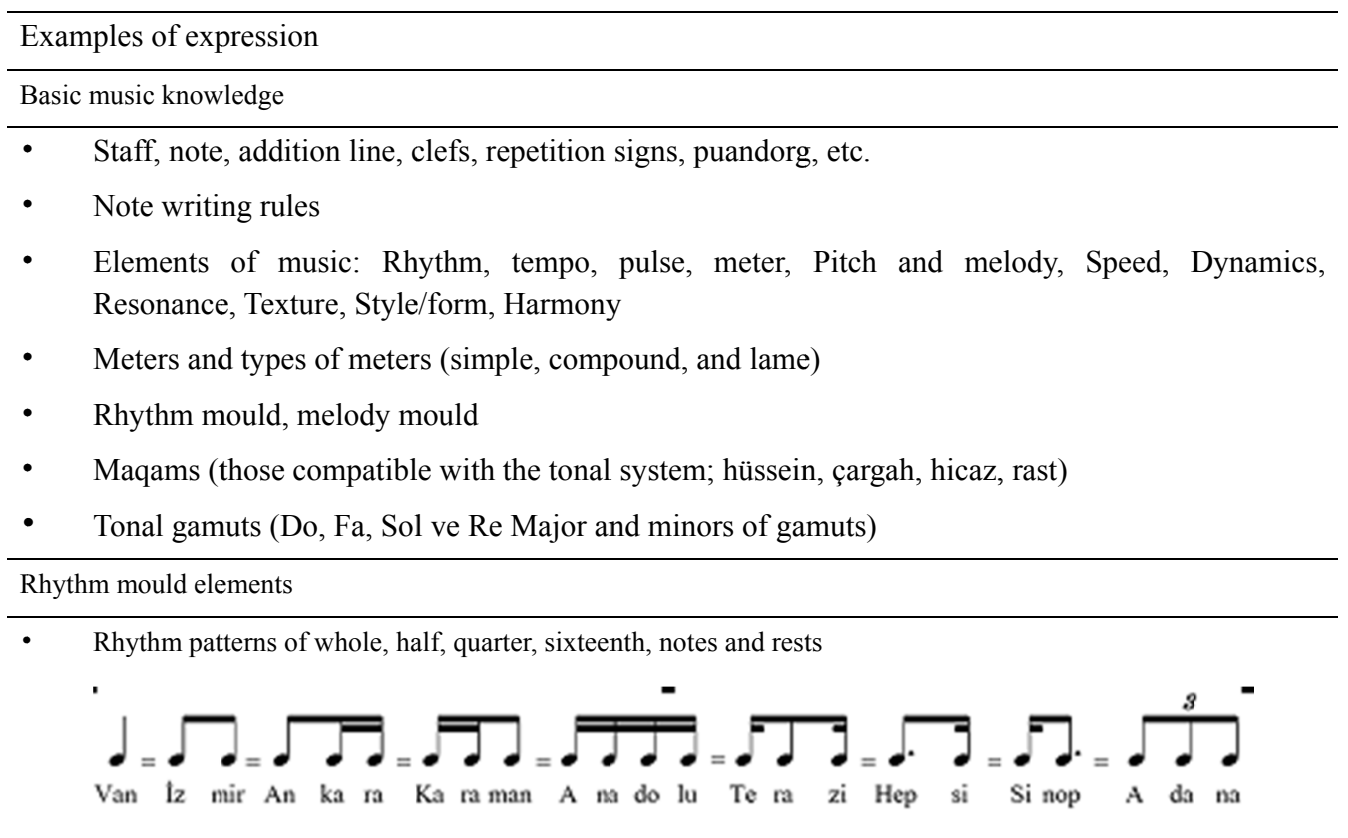

\begin{tabular}{ll}
\hline Using musical note making forms \\
\hline - & Conventional five line stave, Chord symbols, Graphic notation \\
\hline Flute and melodica playing and Solfeges training/selections suitable for one's level of musical \\
\hline - $\quad$ La-sol, la-sol-fa, la-sol-fa-mi, la, sol, fa, mi, re sounds... \\
- $\quad$ Do çargah (Do Major line) \\
- $\quad$ Re hussein (re minör line) \\
\hline Transition from traditional music to contemporary music \\
\hline - $\quad$ Our traditional music: Turkish folk music, Classical Turkish music, Our national anthems, Turkish and \\
$\quad$ western popular music. \\
$\quad$ Contemporary polyphonic Turkish music genres: Contemporary Turkish children's and youth songs, Suites, \\
$\quad$ Turkish sonatas, concertos, and symphonies. Turkish oratorios, operas, and ballets \\
Main genres of international universal music: Child and youth songs, Suites, Various chamber music, \\
$\quad$ Sonatas, concertos, and symphonies \\
\hline Having music repertoire \\
\hline Verbal musics: Nursery rhymes and counting, Folk songs and cradle songs, Turkish school songs, Emulation \\
songs, Carryover songs. \\
Non-verbal: Solfeges, Music arranged for Orff instruments, Polyphonically arranged music for Orff instruments. \\
Children's music with plays \\
\hline
\end{tabular}




\subsubsection{Analysis of "Music Teaching" course content}

Table 5. Analysis of "Music Teaching" course content

\begin{tabular}{l}
\hline Examples of expression \\
\hline Education, Music and Human \\
\hline - $\quad$ What is the education? Why do we get education? \\
$\quad$ Human and music, human and music education \\
1. Three main types of music education: general, voluntary, professional music education) \\
2. Why to study music? (individual, economic, social, cultural, and instructional) \\
- Ataturk's basic views on national culture, Turkish education, and music education and his practices. \\
Methods and Techniques of Music Teaching
\end{tabular}

- General music teaching methods Lecturing, asking and answering questions, problem solving, critical thinking, demonstration, observation, excursion, interviewing, role playing, case study, dramatization, simulating, experiencing

- $\quad$ Special music methods Orff, Dalcroze, Kodaly, Suzuki.

- $\quad$ Teaching-learning strategies will be based on: Lectures, seminars, practical workshops, self-study (tutorial supported)

- Within these four strategies, the following ways of working will be used: Working individually (in small groups and as a whole class), composing, listening, singing by rote and from notation, musical games to reinforce skills and concepts, discussion, teacher-led and student-led activities, integrating the practical and theoretical, cassettes, videos and visual aids, computer-aided learning, guided reading, visits to performances, handouts (supplying information), worksheets (providing interaction), demonstration, assignments, observation of children and other students, practical work with children.

2006-Elementary Music Curriculum (in practice)

- General objectives of Turkish national education, Vision of curriculum, Basic approach and structure of curriculum, Goals and objectives.

- Learning areas (Listening, singing, and performing musical perception and knowledge, Culture of music, Creation of music).

- Activities, Rationale, Music teaching-learning process, Methods and techniques, Assessment (evaluation of students)

Singing

- Speaking, breath, and voice training

- $\quad$ Group singing

Improving Musical Appreciation Through Musical Aesthetic/Listening Relation

- Musical Listening: Turkish folk music, Classical Turkish music, School/education music, Contemporary polyphonic Turkish music, Turkic Republics' Musics, Classical music/chamber music, Turkish and western popular music, Jazz music, Film music, Therapy music, Religious music, Asian and African music.

Forming Song Repertoire

- Song/verbal Repertoire: Nursery rhymes and counting, Cradle songs, folk songs, Turkish school songs, Emulation/imitation songs, Carryover songs, Musics Arranged for Orff instruments.

- Nonverbal music repertoire: Solfege, arrangements with simple rhythms and melodies for orff instruments, polyphonic arrangements for Orff instruments

Relating Music Course Activities (Integrated approaches)

- Intercourses:

Turkish, life study, mathematics, social sciences, science and technology, Turkish republic revolution history and principles of Atatürk, art and history of art.

- Interdisciplines:

Guidance and psychological counseling, developing career awareness, special education field, human rights and citizenship, entrepreneurship.

Preparing and Presenting Project Assignments on Music Elements with Groups 


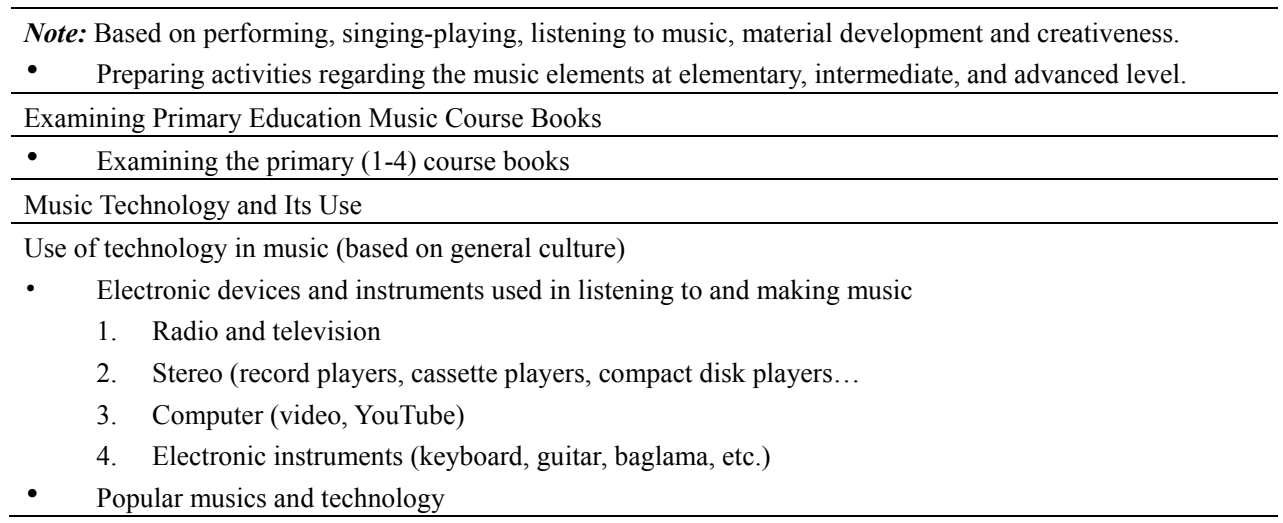

\section{Conclusion and Implications}

Turkey started to train primary school teachers at higher education level since 1974 when music education also became compulsory in the curricula of all institutions that train primary school teachers. Institutions engaged in training primary school teachers were formerly vocational schools that offered 4-year training based on primary school; they were gradually improved and converted into 2-year higher education institutions training teachers from 1974-1975 onward. An examination of the teacher training practices from 1974 to the current date under the university indicated that the aims of the courses and expectations from the education process basically have remained same, even though names and credits/hours of the courses have changed. As result, it can be said that there were no significant changes in curriculum contents, and that they have remained virtually the same.

General characteristics of music education courses that are conducted in primary school teacher education programs values vocational music education rooted from general music education. In turkey, music education courses are divided into two categories; general music education and vocational music education. The former are applied in all school levels without having distinction based on school and program type, while the latter aims to gain skills, knowledge and habits in the field of music education that are needed in some professions. Vocational music education includes courses such as music artistry (composer, singer), directorship education, music teacher education, music education in primary school teacher training, and music education in early childhood teacher training [5]. Music education being applied during the training of primary school and early childhood teacher can be categorized as vocational music education based on general music education.

A close inspection of the course content indicates that teacher training programs historically offer music instruction to pre-service teachers in two course/approaches offerings. One course provides instruction in the fundamentals of music, and a second course provides instruction in content delivery or pedagogy. Music courses that were being offered are based on definitional curriculum model. This model is generally made up of a definition that briefly describes the scope and content of a course. Definitions could mostly be content, operation or activity weighted, partly goal or behavior weighted, repertoire weighted, or materials weighted. Definitional curriculum standards need much analysis because many mysterious expressions hidden in the content of curriculum standards are waiting to be unraveled.

In the current study, music and music teaching courses were presented in a theoretical frame through analysis of behaviors that are included or expected to be included in the music units. Theoretical framework included the steps of investigating, experimenting, revising, and improving definitional curriculum designs. It is assumed that imagination and speculation skills of music educators will be strengthen by this approach that has been designed for resolving the music teaching program that is to be designed, applied and actualized for directing general music teaching process. Within this regard, the current study would also be beneficiary in that it provides new perspectives for music education process that different beliefs, views and practices might ground a base for future experimental teaching processes, and that specialist music educators might find clues in these approaches for their obstacles and might compare them with their own practices. Based on previous explanations, this study is believed to be prominent to contribute on the improvement of music education process. Both the current study and the literature suggests that more effective music training for primary school teachers includes a combination of enhancing musical skills and understandings through meaningful music-making experiences (e.g., exploring, creating, performing, responding, listening, material development) while simultaneously providing experiences to enhance primary school teachers confidence to teach music to children. 


\section{References}

Abrahams, F. (2005). Critical pedagogy for music education: A best practice to prepare future music educators. Visions of Research in Music Education.

Akkaş, S. (2005). Müzik 1-2 Eğitim fakülteleri ilkögretim bölümü slnıf öğretmenliği anabilim dalları için. Ankara: Bilge Ders kitapları.

Ataman, A. (1997). Öğretmen yetiştiren eğitim fakültelerine öğretim elemanı yetiştirilmesi ve eğitimde toplam kalite yönetimi. Yeni Türkiye, 2(7), 382-389.

Barrett, J. R. (2005). Planning for understanding: A conceptualized view of the music curriculum. Music Educators Journal, 91(4), 21-25. https://doi.org/10.2307/3400154

Barrett, J. R. (2007). Currents of Change in the Music Curriculum. In L. Bresler (Ed.), International Handbook of Research in Arts Education. https://doi.org/10.1007/978-1-4020-3052-9_10

Battersby, S. L., \& Cave, A. (2014). Preservice classroom teachers' preconceived attitudes, confidence, beliefs, and self-efficacy tpward integrating music in the elementary curriculum. Update: Applications of Research in Music Education.

Bowen, G. A. (2009). Analysis as a Qualitative Research Method. Qualitative Research Journal, 9(2), 27-40. https://doi.org/10.3316/QRJ0902027

Çiçek, S. (2000). Illköğretimde müzik. Bursa: Ezgi Kitabevi.

Hash, P. M. (2010). Elementary curriculum preservice classroom teachers' attitudes toward music in the elementary curriculum. Journal of Music Teacher Education, 19(2), 6-24. https://doi.org/10.1177/1057083709345632

Kalyoncu, N., \& Öztürk, Ö. (2009). Sinıf öğretmenliği anabilim dallarında verilen müzik ve müzik öğretimi derslerinin içerikleri. 8. Ulusal Müzik Eğitimi Sempozyumu, Samsun: Ondokuz Mayıs Üniversitesi.

Kocabaş, A. (2003). Müzik öğretiminin temelleri. İzmir: Egetan Basım Yayın.

Küçükahmet, L. (1996). Eğitim programları ve öğretim. Ankara: Gazi kitabevi Yayınları.

Mills, J. (2005). Music in the School. New York, NY: Oxford University Press.

Morgül, M. (2001). Müzik nasıl ögretilir çocukluk çağı müzik eğitimi 5-14 yaş. Ankara: Yurt Renkleri Yayınevi.

Overland, C. T. (2013). Integrated arts teaching: What does it mean for music education? Music Educators Journal, 100, 31-37. https://doi.org/10.1177/0027432113497762

Özgül, İ. (2001). Genel müzik eğitimi sinıf öğretmeni yetişstirmede temel yaklaşimlar. Ankara: Gazi Kitabevi Yayınları.

Özgül, İ. (2009). An analysis of the elementary school music teaching course in Turkey. International Journal of Music Education, 27(2), 116-127. https://doi.org/10.1177/0255761409102321

Özgül, İ. (2014). Müzik eğitimi ve öğretimi kuramlar-solfejler-şarkalar-yaklaşımlar (7. bask1). Ankara: PegemAkademi Yayınları.

Özgül, İ. (2015). Changing paradigms in general music education. Educational Research and Reviews, 10(8), 1293-1299.

Phenomenalism. (2017). In Wikipedia, The Free Encyclopedia. Retrieved March 24, 2017, from https://en.wikipedia.org/wiki/Phenomenon

Stock, C. D. (2002). Perspectives in music education and education: the role of national standards for arts education music education policy reform. Eugene: Unpublished Thesis.

Türkiye Cumhuriyeti Milli Eğitim Bakanlı̆̆ [MEB]. (1994). İlköğretim kurumları müzik dersi öğretim programı. Ankara: Milli Eğitim Basımevi.

Türkiye Cumhuriyeti Milli Eğitim Bakanlığı [MEB]. (2006). Illköğretim müzik dersi öğretim program ve klavuzu. Ankara: Milli Eğitim Basımevi.

Türkiye Cumhuriyeti Milli Eğitim Bakanlığı [MEB]. (2008). Stnıf öğretmenliği özel alan yeterlikleri. Ankara: Milli Eğitim Bakanlığı Yayınları.

Türkiye Cumhuriyeti Yüksek Öğretim Kurulu. (1998). Eğitim Fakültesi Öğretmen Yetiştirme Lisans Programlart. Ankara: YÖK Yayınları. 
Türkiye Cumhuriyeti Yüksek Öğretim Kurulu. (2006). Eğitim fakültesi öğretmen yetişstirme lisans programları. Ankara: YÖK Yayınları.

Uçan, A. (2002). Eğitimde program çözümleme. İnönü Üniversitesi Eğitim Fakültesi Dergisi, 3(4), 115-150.

Uçan, A. (2005). Müzik Eğitimi Temel Kavramlar-İlkeler-Yaklaşımlar Türkiye’deki Durum. Ankara: Evrensel Müzikevi.

Yıldırım, A., \& Şimşek, H. (2005). Sosyal Bilimlerde Nitel Araştırma Yöntemleri. Ankara: Seçkin Yayınları.

Yıldız, G. (2002). İlköğretimde müzik öğretimi birinci kademe. Ankara: Anı Yayınları.

\section{Note.}

This work was presented at the 15 World conference on learning, teaching and educational leadership in an oral presentation, 29-30 October 2014, Top Hotel Praha \& Congress Centre Prague/Czech Republic.

\section{Copyrights}

Copyright for this article is retained by the author(s), with first publication rights granted to the journal.

This is an open-access article distributed under the terms and conditions of the Creative Commons Attribution license (http://creativecommons.org/licenses/by/4.0/). 